densities receive super-proportional activation and it is possible so to raise the toe of the curve that the useful intensified densities lie on a straight line.*

The photographic effect here recorded concerns only the 'silver body' of silver sulphide. It is possible that the ordinary sulphide body is equally sensitive but resists decomposition because of rapid recombination of the atoms. More detailed account of this work will appear shortly in the Journal of the Franklin Institute.

Kodak Research Laboratories,

K. Hickman.

Eastman Kodak Company. June 10.

* The commercial applications of the matter contained in this communication are the subject of patent application by the Eastman Kodak Company.

C. Tubandt, $Z$. Electrochem., 26, $358 ; 1920$.

G. Chaperon and C. Mercadier, Compt. rend., 106, 1595; 1888. G. Athanasiu, Compt. rend., 183, 786; 189, 460; 1929 .

W. W. Coblentz and W. B. Emerson, J. Wash. Acad. Sci., 7, 525 ; 1917. F. C. Toy, H. A. Edgerton, J. O. C. Vicks, Phil Mag., (7), 3,

4 'S. E. Sheppard, Phot. J., 48, 380; 1925.

\section{An Inland Record of Aëdes detritus, Haliday (Diptera, Culicidx)}

As investigation was recently carried out by our Institute in the neighbourhood of Droitwich (Worcestershire), where annoyance due to mosquitoes has been experienced from time to time. The trouble proved to be due to the existence of a local breeding area of the two British 'coastal' mosquitoes, Aëdes detritus, Haliday, and Aëdes caspius, Pallas.

Both Aëdes detritus and Aëdes caspius are extremely common in low-lying seaside districts, the presence of larvæ of one or both of these species in collections of stagnant salt, or partly salt, water being probably the rule rather than the exception. Larvæ of Aëdes caspius have also been found occasionally in inland, non-salt, waters - notably at Wimbledon, Mitcham, East Ham and other London suburbs. No instance, however, of Aëdes detritus breeding in an inland locality has previously been recorded in Great Britain.

In the present case, the breeding area consists of a series of parallel ditches in which water, released at intervals from the settling tanks of a sewage works, gradually evaporates and soaks away. Owing to the brine springs for which the district is noted, and to the consequent infiltration of brackish water into the sewers, the water which passes through the settling tanks is more or less saline. While standing in the ditches, this water increases in salinity, partly by evaporation and partly by taking up salt previously deposited in the ground. On the day when the ditches were inspected, the water (which was teeming with larvæ and pupæ of both of the abovementioned species) was about one quarter as salt as the sea.

The ditches are narrow and easily accessible, so that the prevention of further mosquito breeding by means of oil or larvicides is a comparatively simple matter.

It is perhaps reasonable to assume that Aëdes detritus was at some time introduced into the Droitwich area from a coastal district, but no evidence is available to indicate how or when such introduction can have occurred. It is interesting, however, to note $(a)$ that the eggs of this species are able to survive long periods of desiccation, and $(b)$ that, up to comparatively recent times, salt-carrying barges plied continuously between Droitwich and the Bristol Channel.

Although this case is a unique one so far as Great Britain is concerned, larvæ of Aëdes detritus have been found inland in northern Germany on two occasions - at Oldesloe and at Lüneburg. In both these districts, as in Droitwich, extensive salt deposits exist.

British Mosquito Control Institute,

John F. Marshall. Hayling Island, Hants. June 30 .

\section{Adaptations to Hydrostatic Pressure in Whales}

INVESTIGATIONs into the circumstances of respiration in Southern Blue Whales have been carried out in South Georgia and on board a floating factory. Photomicrographs of the lungs, suitably stained, show each alveolus to be encased in elastic tissue. Cartilage is found in the smaller bronchioles. Placental arteries and veins are reinforced in spongy tissue so that the thickness of the walls is more than twice the internal diameter of the vessel.

Gas analyses of urine and allantoic fluid indicate that slight supersaturation is chronic. The volumes of dissolved carbon dioxide, which is found in great quantity, postulate various partial pressures of this gas from $220 \mathrm{~mm}$. to $480 \mathrm{~mm}$. of mercury. No appreciable amounts of dissolved oxygen have been detected.

The blood of a freshly killed whale would be expected to show supersaturation with nitrogen. This is scarcely ever the case. Of. 110 samples of adult and fœetal blood, one only contained more nitrogen than was soluble in the blood at atmospheric pressure ; the majority contained less. Whale's blood takes up slightly more than two volumes per cent nitrogen from the air; human blood, about $1 \cdot 2$.

Further examination shows the presence of small organisms (diameter, $0 \cdot 5-3 \mu$ ) in the blood of all Blue Whales and their foetuses to the extent of approximately 20 million per c.mm. These organisms are motile and reproduce in blood kept in vitro and in nutrient solution. They have been shown to adsorb nitrogen, thus accounting for the extra solubility of nitrogen in blood mentioned above. Nitrogen which has been taken up is recoverable only by immediate evacuation. After a few minutes the nitrogen disappears and is not recoverable by evacuation. This points to some form of fixation such as occurs in certain free-living bacteria. The rate of fixation of nitrogen has been measured by a method which does not allow of continuous mixing of the gas with the blood. Various rates up to 2.8 volumes per cent in 40 minutes have been observed at room temperature. No fixation occurs in whale's blood in the absence of oxygen. The organisms have been seen, in whale's blood which was almost devoid of oxygen, to attack the erythrocytes and burst their envelopes.

This mechanism, which removes from the blood the excess nitrogen naturally resulting from compression of the lungs in deep diving, seems appropriate to an aquatic mammal of the whale's habit of life. In the absence of this defence, a whale would be liable to conditions which cause caisson sickness on returning to the surface after a deep dive.

In whale's blood which was brought from the antarctic at $-10^{\circ} \mathrm{C}$. the organisms are still active, 